\title{
Nigella sativa as an anti-inflammatory agent in asthma
}

\author{
Mukhtar Ikhsan ${ }^{1,2}$, Nurul Hiedayati ${ }^{3}$, Kazutaka Maeyama ${ }^{4}$ and Fariz Nurwidya ${ }^{1,5^{*}}$ (D)
}

\begin{abstract}
Objective: Nigella sativa (N. sativa) has several pharmacological actions which include antioxidant, antidiabetic, anticancer, antitussive, immunomodulator, analgesic, antimicrobial, anti-inflammatory, spasmolytic, and bronchodilator. The purpose of this study is to measure the effectivity of N. sativa ethanol extract as anti-inflammation on peritoneal Wistar rat mast cells. The laboratory experiment was used to investigate the effectivity of N. sativa as an anti-inflammatory on mast cells. Six groups of mast cells were stimulated by C $48 / 80$ to release histamine. Group 1 were without N. sativa, while group 2,3,4,5, and 6 were given N. sativa with concentrations of $0.1 \mathrm{mg} / \mathrm{ml}, 0.2 \mathrm{mg} /$ $\mathrm{ml}, 0.3 \mathrm{mg} / \mathrm{ml}, 0.4 \mathrm{mg} / \mathrm{ml}$ and $0.5 \mathrm{mg} / \mathrm{ml}$, respectively. Histamine concentration was measured by high-performance liquid chromatography-fluorometry.

Result: The study showed that N. sativa ethanol extract effectively inhibit histamine release from peritoneal Wistar rat mast cells proportionally to its concentration. $N$. sativa is effective as an anti-inflammation on mast cells by inhibition of histamine release and has no toxic effect on mast cell. N. sativa could be considered as a potential therapy for asthma therapy and prevention.
\end{abstract}

Keywords: Nigella sativa, Anti-inflammatory, Asthma

\section{Introduction}

The seeds of the annual flowering plant, Nigella sativa (N. Sativa), have been prized for their healing properties and was popularly used in traditional medicine systems such as Greece, Ayurveda and Siddha [1]. N. sativa is also mentioned in the Bible [2]. Furthermore, Imam Bukhari and Imam Muslim have narrated that Prophet Muhammad (peace be upon him) said: "Hold on to the use of the habbat al-sauda (N. sativa) for indeed it has a remedy for every disease except death" [3]. N. sativa has a broad spectrum of pharmacological actions, including antioxidant, antidiabetic, anticancer, antitussive, immunomodulator, analgesic, antimicrobial, anti-inflammatory, spasmolytic, and bronchodilator [4].

Asthma is one of the major health problems in the world. There is a difference in the prevalence of asthma

\footnotetext{
${ }^{*}$ Correspondence: fariz.nurwidya@gmail.com

${ }^{1}$ Department of Pulmonology and Respiratory Medicine, Faculty of Medicine Universitas Indonesia, Persahabatan Hospital, Jalan Persahabatan Raya No.1, Rawamangun, Jakarta 13230, Indonesia Full list of author information is available at the end of the article
}

in different countries that varies from 1 to $18 \%$. In Indonesia asthma is the top ten cause of morbidity and mortality, as illustrated by Household Health Survey (Survei Kesehatan Rumah Tangga, SKRT) data in various provinces in Indonesia [5].

Asthma is a chronic inflammatory disease of the airways. Various inflammatory cells involved primarily mast cells, eosinophils, $\mathrm{T}$ lymphocytes, macrophages, neutrophils, and epithelial cells. Environmental factors and other factors play a role in causing or triggering airway inflammation in asthma. Inflammation is present in various degrees of asthma in both intermittent and persistent asthma. Inflammation can be found in various forms of asthma such as allergic asthma, non-allergic asthma, work asthma and asthma triggered by aspirin [6].

Mast cells are the most important cells in the early stages of an asthma attack. Mast cells have high-affinity immunoglobulin-E (IgE) receptors. Cross-linking IgE receptors with factors in mast cells activates mast cells. There is degranulation of mast cells that release preformed mediators such as histamine and proteases as

C The Author(s) 2018. This article is distributed under the terms of the Creative Commons Attribution 4.0 International License (http://creativecommons.org/licenses/by/4.0/), which permits unrestricted use, distribution, and reproduction in any medium, provided you give appropriate credit to the original author(s) and the source, provide a link to the Creative Commons license, and indicate if changes were made. The Creative Commons Public Domain Dedication waiver (http://creativecommons.org/ publicdomain/zero/1.0/) applies to the data made available in this article, unless otherwise stated. 
well as newly generated mediators such as prostaglandin D2 and leukotriene. Mast cells also release cytokines such as tumor necrosis factor- $\alpha$ (TNF- $\alpha)$, interleukin (IL)-3, IL-4, IL-5 and granulocyte-macrophage-colonystimulating factor (GM-CSF) [6].

The previous study showed that $N$. sativa significantly inhibited mast cell degranulation and reduced mast cells population induced by Tricholoma terreum [7]. Furthermore, $N$. sativa seed extract also decreased intestinal mast cell numbers and plasma mouse mast cell protease- 1 (MMCP-1) in the hypersensitive murine model [8]. In the form of oil, $N$. sativa significantly decreases airway hyperresponsiveness through the reduced number of leukocytes, macrophages, eosinophils, and levels of several asthma-related interleukins [9]. In addition, Khaldi et al. have demonstrated $N$. sativa oil administration had antiinflammatory effects by reducing interleukin 4 (IL-4) and nitrite oxide (NO) production in rat asthma model [10]. In a single-blind randomized clinical trial, $N$ sativa supplementation with inhaled maintenance therapy increase asthma control test (ACT) score, improve lung function and reduce IgE levels in partly controlled asthma subjects [11]. The current study was conducted to assess the toxicity of $N$. sativa ethanol extract on mast cell and effectivity of $N$. sativa ethanol extract in histamine release inhibition from peritoneal Wistar rat mast cells which received stimulation by $\mathrm{C} 48 / 80$.

\section{Main text}

\section{Materials and methods}

Identification of $N$. sativa seeds was performed at the Center of Biopharmaceutical Studies, Bogor Agricultural University, Bogor, Indonesia. In vivo and in vitro experiments were performed at the Department of Pharmacology, Informational Biomedicine, Ehime University Graduate School of Medicine, Ehime, Japan.

\section{Preparation of N. sativa ethanol extract}

The dried $N$. sativa seed was crushed and extracted with a ratio of $1 \mathrm{~g}$ of sample with $10 \mathrm{ml}$ of $50 \%$ ethanol solvent for $12 \mathrm{~h}$ three times. The extraction results were filtered with Whitman filter paper and saturated with a vacuum rotator at a temperature of $30^{\circ} \mathrm{C}$.

\section{Purification of peritoneal Wistar rat mast cells}

The Wistar rats were housed in a temperature of $25{ }^{\circ} \mathrm{C}$ room with a sufficient light and dark cycle and a relative humidity of $55 \%$. Irradiated food and pure water and were provided ad libitum. All procedures performed on the animals were approved by the Institutional Review Board (IRB) of Faculty of Medicine Universitas Islam Syarif Hidayatullah, Jakarta, Indonesia (Ethical Approval No. Un.01/F10/KP.01.1/KE.SP/05.12.001/2011) in 2011.
Wistar rats were sacrificed by ether anesthesia. Cells from the peritoneal cavity were recovered by washing the peritoneal cavity with phosphate-buffered saline (PBS) containing heparin. Purification of mast cells was performed with a Percoll density gradient. The mast cells were then calculated by staining with Toluidin blue $\mathrm{pH} 2.5$ and viable mast cells were counted by trypan blue paint.

\section{Preparation of $N$. sativa solution}

Nigella sativa extract was dissolved in dimethyl sulfoxide (DMSO), and then dissolved in Pipe Siragainan (PIPES) buffer. The $0.4 \%$ DMSO solution did not stimulate the release of histamine by mast cells, and PIPES buffer was used for the control group. Compound (C) 48/80 solution with a concentration of $10 \mu \mathrm{g} / \mathrm{ml}$ was used to stimulate the release of histamine from mast cells as much as $85 \%$.

\section{Measurement of histamine level}

Histamine was measured by high-performance liquid chromatography (HPLC)-fluorometry according to manufacturer protocols. After $30 \mathrm{~min}$ incubated with $\mathrm{C}$ 48/80, 96 well plates were centrifuged at $3000 \mathrm{rpm}$ for $5 \mathrm{~min}$ and $50 \mu \mathrm{l}$, supernatant was taken and placed on a $1.5 \mathrm{ml}$ plastic tube and added $250 \mu \mathrm{l}$ of $3 \%$ perchloric acid containing $5 \mathrm{mM} \mathrm{Na} 2$-ethylene-diamine-tetra-acetic acid (EDTA), after addition of $30 \mu \mathrm{l} 2 \mathrm{M} \mathrm{KOH} / 1 \mathrm{M} \mathrm{KH} 2 \mathrm{PO} 4$ and centrifuged at $10,000 \times g$ for $15 \mathrm{~min}$ at $4^{\circ} \mathrm{C}, 50 \mu \mathrm{l}$ supernatant was injected in TSKgel column of SP-2SW cation exchanger (Tosoh, Tokyo). To measure the total content of histamine in mast cells, the remainder of the mast cell solution at the well was destroyed by sonication then $50 \mu \mathrm{l}$ was used to measure histamine.

Histamine was diluted with $0.25 \mathrm{M}$ potassium phosphate with a flow rate of $0.6 \mathrm{ml} / \mathrm{min}$, then labeled with $o$-phthalaldehyde under alkaline conditions and detected with F1080 Fluorometer (Hitachi, Tokyo) on excitation and emission 360 and $450 \mathrm{~nm}$, respectively.

\section{Calculation of histamine release percentages}

The percentage of net histamine release (\%) was calculated by the following formula $=$ (histamine content of stimulated mast cell supernatant-histamine content in unstimulated mast cell supernatant)/(total histamine content - histamine content in unstimulated mast cells) $\times 100$. Meanwhile, the percentage of spontaneous histamine release (\%) was obtained by the following formula $=$ (histamine content in unstimulated mast cell supernatant) $/($ total histamine content $) \times 100$. As for the percentage of inhibition of histamine release (\%), this formula was used $=$ (histamine release in supernatant of mast cells stimulated in the absence of $N$. sativa extract - histamine release in mast cell supernatant stimulated by the presence of $N$. sativa extract)/(histamine 
release in mast cell supernatant stimulated in the absence of $N$. sativa extract) $\times 100$.

\section{Data processing and statistical analysis}

All data were described as the mean \pm standard error of the mean (SEM). The data were statistically analyzed using analysis of variances (ANOVA) followed by the least significant difference (LSD). The significance limit was $\mathrm{p}<0.05$.

\section{Results}

\section{Toxicity of Nigella sativa}

First, we examined the toxicity of $N$. sativa on mast cells. Figure 1 showed the histamine release from mast cells without stimulation by $\mathrm{C} 48 / 80$. Without stimulation by C $48 / 80$ compound, to a concentration of $0.5 \mathrm{mg} / \mathrm{ml}$ of $N$. sativa ethanol extract did not result in significant spontaneous histamine release $(<10 \%)$. One point $77 \%$ at the concentration of $0,2.28 \%$ at the concentration of $0.1 \mathrm{mg} /$ $\mathrm{ml}, 2.38 \%$ at the concentration of $0.2 \mathrm{mg} / \mathrm{ml}, 2.25 \%$ at the concentration of $0.3 \mathrm{mg} / \mathrm{ml}, 2.63 \%$ at the concentration of $0.4 \mathrm{mg} / \mathrm{ml}$ and $2.74 \%$ at the concentration of $0.5 \mathrm{mg} /$ $\mathrm{ml}$, respectively. The results did not differ significantly in the control group in which the histamine release is $1.77 \%$. These data showed that $N$. sativa ethanol extract did not result in damage (lysis) to mast cells.

\section{Effectivity of Nigella sativa in histamine release inhibition}

Next, we determined the effectivity of $N$. sativa ethanol extract in the histamine release inhibition. Figure 2 showed the effect of histamine release inhibition by $N$. sativa ethanol extract after stimulated by C $48 / 80$. The greater concentration of $N$. sativa ethanol extract resulted the greater inhibition effect, $4.54 \%$ in concentration of $0.1 \mathrm{mg} / \mathrm{ml}, 22.4 \%$ in concentration of $0.2 \mathrm{mg} / \mathrm{ml}$, $35.38 \%$ in the concentration of $0.3 \mathrm{mg} / \mathrm{ml}, 75.43 \%$ in the

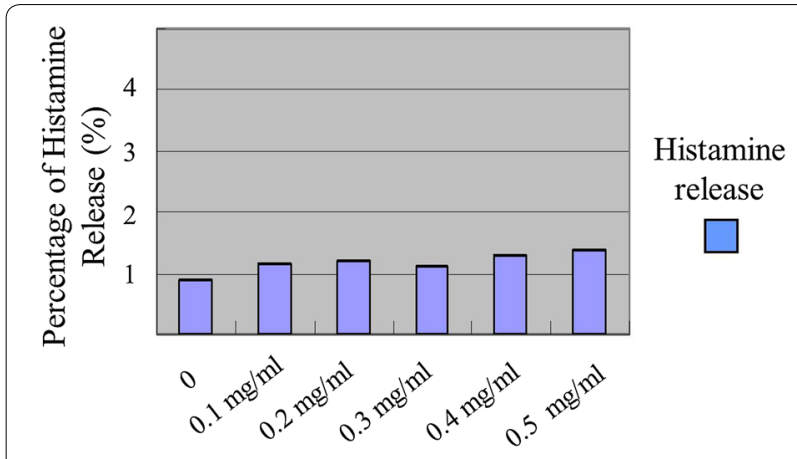

Fig. 1 Effect of various concentrations of $N$. sativa ethanol extract on histamine release in mast cells without stimulation by $C 48 / 80$. Each data describes the mean \pm SEM of 5 experiments with triplication ( $\mathrm{n}$ : 15)

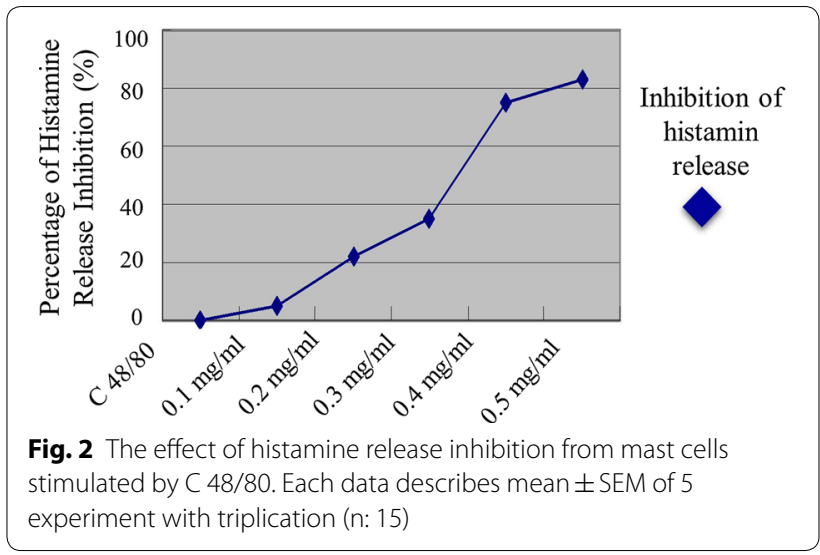

concentration of $0.4 \mathrm{mg} / \mathrm{ml}$ and $83.42 \%$ in the concentration of $0.5 \mathrm{mg} / \mathrm{ml}$. The study showed that $N$. sativa ethanol extract can inhibit histamine release from peritoneal Wistar rat mast cells stimulated by $\mathrm{C} 48 / 80$ proportionally to its concentration.

\section{Discussion}

Treatment of asthma by an agent with sufficient safety level is important and under intensive investigation. With the known pharmacological action of $N$. Sativa, it is necessary to determine the toxicity aspect at the cellular level. We found that $N$. Sativa caused no toxicity to mast cells. This study results are similar to the study result by Dollah et al. who performed a study to determine the toxic effect of $N$. sativa powder on the kidney function which was evaluated by serum urea and creatinine and through histopathological examination of kidney tissue. They found that there is no toxic effect on kidney function of $N$. sativa at different doses for 5-week period of treatment [12]. Another study also showed that supplementation of $N$. sativa up to the dose of $1 \mathrm{~g} / \mathrm{kg}$ supplemented for a period of 28 days resulted in no changes in liver enzymes level and did not cause any toxicity effect on the liver function [13].

Mast cells played important role in the inflammation of airway in asthma due to their capacity to release histamine. We showed in this study that $N$. sativa was effective in the inhibition of histamine release by mast cells. The previous study has revealed that thymoquinone (one of the active substances of $N$. sativa) attenuates the inflammatory response in activated mast cells by blocking transcription and production of TNF $\alpha$ through modulation of the proinflammatory transcription factor nuclear factor- $\kappa B(N F-\kappa B)$ [14]. Furthermore, thymoquinone can inhibit leukotriene formation in human blood, through the inhibition of both 5-lipoxygenase and leukotriene C4 (LTC4)-synthase activity [15]. Thymoquinone has a 
function as an anti-inflammatory, anti-oxidant, and antiallergic which highlights the potency of thymoquinone to treat airway hypersensitivity-related diseases including asthma [16].

Boskabady et al. studied the preventive effect of a hydro-ethanolic extract of $N$. sativa on the tracheal responsiveness and white blood cell count in the lung lavage fluid of sensitized guinea pigs. The results demonstrate the preventive effect of the $N$. sativa extract on the tracheal response and lung inflammation in sensitized guinea pigs [17].

Several clinical studies have been performed to assess the anti-inflammation features of N. Sativa in asthmatic subjects. Boskabady et al. studied the effects of $N$. sativa boiled extract as anti-asthma in asthmatic patients and the results showed that the extract caused significant increases in all measured pulmonary function tests [18]. The prophylactic effects of $N$. sativa boiled extract was also confirmed in a study involving 29 asthmatic patients. Among the $N$. sativa group, the use of oral inhalers and beta-agonists, oral corticosteroids, oral theophylline, and even corticosteroid inhalers decreased at the end of the study while no apparent change in the use of drugs in the control group [19].

In a study, treatment with $N$. sativa oil supplementation resulted in improvement on clinical and inflammatory parameters of asthma such as ACT score, pulmonary function test, blood eosinophils and total serum Immunoglobulin E [20]. Moreover, supplementation with $N$. sativa oil improves interferon- $\gamma(\mathrm{IFN}-\gamma) / \mathrm{IL}-4$ balance and ACT in children with asthma [21]. These studies suggest that $N$. sativa might improve the clinical outcome of a patient with asthma through the various pathways within the spectrum of asthma pathophysiology.

As a conclusion, $N$. sativa ethanol extract has no toxic effect on mast cells and is effective as an anti-inflammatory by histamine release inhibition from mast cells. The anti-inflammatory features of $N$. sativa are promising in the prevention and therapy of asthma.

\section{Limitations}

The current study only investigated the effect of $N$. sativa on histamine release, meanwhile, various active effector substrate are involved in the asthma symptoms, including leukotriene. Furthermore, there is a need to explore what signaling pathway that is inhibited by $N$. sativa, considering to the complexity of interleukins that mediate the release of histamine by mast cells.

\section{Abbreviations}

ACT: asthma control test; DMSO: dimethyl sulfoxide; EDTA: ethylene-diaminetetra-acetic acid; GM-CSF: granulocyte-macrophage-colony-stimulating factor; IFN- $\gamma$ : interferon- $\gamma$; IgE: immunoglobulin-E; IL: interleukin; LTC4: leukotriene
C4; MMCP-1: mast cell protease-1; NO: nitrite oxide; NF-kB: nuclear factor-kB; PBS: phosphate-buffered saline; PIPES: Pipe Siragainan; SEM: standard error of the mean; SKRT: survei kesehatan rumah tangga (Household Health Survey); TNF-a: tumor necrosis factor-a.

\section{Authors' contributions}

$\mathrm{MI}$ contributed in the study concept, design, literature search, experimental studies, data acquisition, data analysis, statistical analysis, manuscript preparation, and final approval of the manuscript. $\mathrm{NH}$ contributed in the experimental studies, data acquisition, data analysis, statistical analysis, manuscript editing, and final approval of the manuscript. MK contributed in the study concept, design, literature search, experimental studies, data acquisition, data analysis, statistical analysis, manuscript preparation, and final approval of the manuscript. FN contributed in the literature search, data analysis, statistical analysis, manuscript editing, manuscript review. All authors read and approved the final manuscript.

\begin{abstract}
Author details
${ }^{1}$ Department of Pulmonology and Respiratory Medicine, Faculty of Medicine Universitas Indonesia, Persahabatan Hospital, Jalan Persahabatan Raya No.1, Rawamangun, Jakarta 13230, Indonesia. ${ }^{2}$ Department of Pulmonology and Respiratory Medicine, Faculty of Medicine and Health Sciences Universitas Islam Negeri Syarif Hidayatullah, Jakarta, Indonesia. ${ }^{3}$ Department of Pharmacology, Faculty of Medicine and Health Sciences Universitas Islam Negeri Syarif Hidayatullah, Jakarta, Indonesia. ${ }^{4}$ Department of Pharmacology, Informational Biomedicine, Ehime University Graduate School of Medicine, Shitsukawa, Toon, Ehime 791-0295, Japan. ${ }^{5}$ Department of Nutrition, Faculty of Medicine Universitas Indonesia, Dr. Cipto Mangunkusumo Hospital, Jakarta, Indonesia.
\end{abstract}

\section{Acknowledgements}

We would like to acknowledge the Center of Biopharmaceutical Studies, Bogor Agricultural University, Indonesia, for the identification of N. sativa seeds.

\section{Competing interests}

The authors declare that they have no competing interests.

\section{Availability of data and materials}

The data set supporting the conclusions of this article can be obtained from the authors upon reasonable request.

\section{Consent to publish}

Not applicable.

Ethics approval and consent to participate

The study has been approved by the Institutional Review Board (IRB) of Universitas Islam Negeri Syarif Hidayatullah.

Funding

None.

\section{Publisher's Note}

Springer Nature remains neutral with regard to jurisdictional claims in published maps and institutional affiliations.

Received: 21 August 2018 Accepted: 16 October 2018

Published online: 19 October 2018

\section{References}

1. Ahmad A, Husain A, Mujeeb M, Khan SA, Najmi AK, Siddique NA, et al. A review on therapeutic potential of Nigella sativa: a miracle herb. Asian Pac J Trop Biomed. 2013;3(5):337-52. https://doi.org/10.1016/S2221 -1691(13)60075-1.

2. The Bible, Old Testament [Alkitab Perjanjian Lama Ibrani Indonesia]. Isaiah. 2013;25:25, 27.

3. Al-Jawziyya IQ. Medicine of the Prophet. English language translation. (c) Penelope Johnstone. Cambridge: The Islamic Text Society; 1988. p. 215. 
4. Tavakkoli A, Ahmadi A, Razavi BM, Hosseinzadeh H. Black seed (Nigella Sativa) and its constituent thymoquinone as an antidote or a protective agent against natural or chemical toxicities. Iran J Pharmaceutical Res. 2017; 16: 2-23. http://ijpr.sbmu.ac.ir/article_2003.html. Accessed 29 Jan 2018.

5. Ratnawati. Editorial: epidemiology of asthma. J Respir Indo. 2011;31(4):172-5

6. Indonesian Society of Respirology [Perhimpunan Dokter Paru Indonesia (PDPI)]. Guideline of Asthma Treatment in Indonesia [Pedoman Penatalaksanaan Asma di Indonesia]. Jakarta: PDPI; 2013. p. 7.

7. Kilinc E, Dagistan Y, Kotan B, Cetinkaya A. Effects of Nigella sativa seeds and certain species of fungi extracts on number and activation of dural mast cells in rats. Physiol Int. 2017;104(1):15-24. https://doi. org/10.1556/2060.104.2017.1.8.

8. Duncker SC, Philippe D, Martin-Paschoud C, Moser M, Mercenier A, Nutten S. Nigella sativa (black cumin) seed extract alleviates symptoms of allergic diarrhea in mice, involving opioid receptors. PLoS ONE. 2012;7(6):e39841. https://doi.org/10.1371/journal.pone.0039841.

9. Balaha MF, Tanaka H, Yamashita H, Abdel Rahman MN, Inagaki N. Oral Nigella sativa oil ameliorates ovalbumin-induced bronchial asthma in mice. Int Immunopharmacol. 2012;14(2):224-31. https://doi. org/10.1016/j.intimp.2012.06.023.

10. Khaldi T, Chekchaki N, Boumendjel M, Taibi F, Abdellaoui M, Messarah M, et al. Ameliorating effects of Nigella sativa oil on aggravation of inflammation, oxidative stress and cytotoxicity induced by smokeless tobacco extract in an allergic asthma model in Wistar rats. Allergol Immunopathol (Madr). 2018;46(5):472-81. https://doi.org/10.1016/j.aller.2018.02.005s.

11. Salem AM, Bamosa AO, Qutub HO, Gupta RK, Badar A, Elnour A, et al. Effect of Nigella sativa supplementation on lung function and inflammatory mediatorsin partly controlled asthma: a randomized controlled trial. Ann Saudi Med. 2017:37(1):64-71. https://doi. org/10.5144/0256-4947.2017.64.

12. Dollah MA, Parhizkar S, Izwan M. Effect of Nigella sativa on the kidney function in rats. Avicenna J Phytomed. 2013;3(2):152-8. https://doi. org/10.22038/AJP.2013.5.
13. Dollah MA, Parhizkar S, Latiffah AL, Hassan MHB. Toxicity effect of Nigella sativa on the liver function of rats. Adv Pharm Bull. 2013;3(1):97-102. https://doi.org/10.5681/apb.2013.016.

14. El Gazzar MA, Mezayen RE, Nicolls MR, Dreskin SC. Thymoquinone attenuates proinflammatory responses in lipopolysaccharide-activated mast cells by modulating NF-kappaB nuclear transactivation. Biochim Biophysic Acta. 2007;1770:556-64. https://doi.org/10.1016/j.bbage n.2007.01.002.

15. Mansour M, Tornhamre S. Inhibition of 5-lipoxygenase and leucotriene $\mathrm{C}_{4}$ synthase in human blood cells by thymoquinone. J Enzyme Inhibition Med Chem. 2004;19(5):431-6. https://doi.org/10.1080/147563604000020 72.

16. Abd El Aziz AE, El Sayed NS, Mahran LG. Anti-asthmatic and anti-allergic effects of thymoquinone on airway-induced hypersensitivity in experimental animals. J Applied Pharm Sci. 2011; 1(08): 109-17. http://www. japsonline.com/abstract.php?article_id=223. Accessed 10 Feb 2018.

17. Boskabady MH, Keyhanmanesh R, Khamneh S, Ebrahimi MA. The effect of Nigella sativa extract on tracheal responsiveness and lung inflammation in ovalbumin sensitized guinea pigs. Clinics. 2011;66(5):879-87. https:// doi.org/10.1590/S1807-59322011000500027.

18. Boskabady MH, Mohsenpoor N, Takaloo L. Anti-asthmatic effect of Nigella sativa in airways of asthmatic patients. Phytomed. 2010;17(10):707-13. https://doi.org/10.1016/j.phymed.2010.01.002.

19. Boskabady MH, Javan H, Sajady M, Rakhshandeh H. The possible prophylactic effect of Nigella sativa seed extract in asthmatic patients. Fundam Clin Pharmacol. 2007;21(5):559-66. https://doi.org/10.111 1/j.1472-8206.2007.00509.x.

20. Koshak A, Wei L, Koshak E, Wali S, Alamoudi O, Demerdash A, et al. Nigella sativa supplementation improves asthma control and biomarkers: a randomized, double-blind, Placebo-Controlled Trial. Phytother Res. 2017:31(3):403-9. https://doi.org/10.1002/ptr.5761.

21. Barlianto W, Rachmawati M, Irawan M, Wulandari D. Effects of Nigella sativa oil on Th1/Th2, cytokine balance, and improvement of asthma control in children. Paediatr Indones. 2017;57(5):223-8. https://doi. org/10.14238/pi57.5.2017.223-8.
Ready to submit your research? Choose BMC and benefit from:

- fast, convenient online submission

- thorough peer review by experienced researchers in your field

- rapid publication on acceptance

- support for research data, including large and complex data types

- gold Open Access which fosters wider collaboration and increased citations

- maximum visibility for your research: over 100M website views per year

At BMC, research is always in progress.

Learn more biomedcentral.com/submissions 